\title{
ПОРІВНЯЛЬНА МОРФОМЕТРИЧНА ОЦІНКА ПРОЦЕСІВ РЕГЕНЕРАЦІї ТКАНИН ПЕРЕДНЬОЇ ЧЕРЕВНОЇ СТІНКИ ПІСЛЯ ІМПЛАНТАЦІї РІЗНИХ ТИПІВ ПОЛІПРОПІЛЕНОВИХ СІТОК В ЕКСПЕРИМЕНТІ
}

\section{๑В. І. П'ятночка, М. С. Гнатюк \\ ДВНЗ «Тернопільський державний медичний університет імені І. Я. Горбачевського МОз України»}

РЕЗЮМЕ. Широке впровадження в хірургічну практику сучасних алопластичних матеріалів суттєво покращило результати хірургічного лікування хворих на вентральну та післяопераційну вентральну грижі. Проте імплантація синтетичного матеріалу в тканини передньої черевної стінки супроводжується різними місцевими реакціями, особливо при використанні «важких» сіток, що часто призводить до розвитку ускладнень. Необхідність аналізу отриманих результатів зумовлює актуальність даного дослідження.

Мета роботи-провести морфометричну оцінку змін артерій м'язово-апоневротичного шару після імплантації «важких» та «легких» поліпропіленових сіток, а також «легких» в комбінації з PRF мембраною.

Матеріал і методи. Морфометричний аналіз артерій м'язово-апоневротичного шару після імплантації «важких», «легких" поліпропіленових сіток, а також «легких» в комбінації з PRF мембраною, за допомогою світлооптичного дослідження мікропрепаратів. Експерименти виконані на 18 статевозрілих свинях-самцях в'єтнамської породи, які були поділені на 6 груп.

Результати. Виміри, проведені в групі інтактних тварин, показали, що зовнішній діаметр артерій дрібного калібру дорівнював $(35,80 \pm 0,24)$ мкм, внутрішній - $(12,60 \pm 0,15)$ мкм, товщина медії - $(10,50 \pm 0,09)$ мкм, індекс Керногана (відношення площі просвіту до всієї площі судини) становив $(12,40 \pm 0,12) \%$. Висота ендотеліоцитів цих судин досягала $(6,20 \pm 0,03)$ мкм, діаметр їх ядер - $(2,98 \pm 0,02)$ мкм. Ядерно-цитоплазматичні відношення у досліджуваних клітинах дорівнювали $(0,230 \pm 0,003)$. На 28-му добу експерименту за умов імплантації «легкої» сітки товщина медії судин дорівнювала $(10,90 \pm 0,12)$ мкм. Цей морфометричний параметр на 3,8 \% перевищував аналогічний контрольний і статистично достовірно (p<0,05) від нього відрізнявся. При імплантації «легкої» сітки в комбінації з PRF мембраною відбувалися зміни відносного об'єму пошкоджених ендотеліоцитів у артеріях дрібного калібру. У 1-й групі спостережень вказаний морфометричний параметр дорівнював $(2,40 \pm 0,03) \%$, а у 4-й - $(2,60 \pm 0,09) \%$. Морфометричні параметри артерій дрібного калібру при імплантації «важкої» сітки були такими: зовнішнішній діаметр вказаних судин збільшився всього на 0,22 \%, а внутрішній діаметр майже не змінився і дорівнював $(12,70 \pm 0,18)$ мкм. Товщина медії артерій дрібного калібру передньої черевної стінки виявилася збільшеною і досягала $(10,92 \pm 0,15)$ мкм. Цей морфометричний параметр статистично достовірно $(p<0,05)$ відрізнявся від аналогічного контрольного $(10,50 \pm 0,09)$ мкм. Виявлена різниця між наведеними морфометричними параметрами дорівнювала 4,0\%.

Висновки. У результаті морфометричних вимірювань артерій дрібного калібру встановлено, що імплантація «легкої» сітки, порівняно із "важкою», у віддаленому періоді експерименту призводила до вираженішого ремоделювання досліджуваних судин, що підтверджувалося відносним об'ємом пошкоджених ендотеліоцитів, який, відповідно, дорівнював $(4,10 \pm 0,05)$ \% та $(4,90 \pm 0,05)$ \%. Використання для імплантації «легкої» сітки 3 PRF мембраною приводило до найменш вираженішої структурної перебудови артерій.

КЛючОВІ СлОВА: імплантація; поліпропіленова сітка; морфометрія артерій; товщина медії; індекс Керногана.

Вступ. На сьогодні при хірургічному лікуванні вентральних та післяопераційних вентральних гриж операцією вибору є алопластика. Проте не завжди виконання алогерніопластики забезпечує надійність виконання операційного втручання $[4,6,14]$. В групі пацієнтів з післяопераційними вентральними грижами та іншими супутніми захворюваннями, що супроводжуються ареактивністю організму, виконання оперативного втручання з використанням сітчастих імплантів не завди дозволяє домогтися очікуваного результату. Через високу частоту післяопераційних ускладнень $(11,8-50 \%)$ та рецидивів хвороби (6,5-15\%), хірурги постійно розробляють нові способи алогерніопластик $[2,3,5]$.

Морфометрична картина реакції тканин в зоні імплантації поліпропіленової сітки досі недостатньо вивчена і висвітлена $[7,8,10,11]$.
Цікавим, на наш погляд, $є$ і поглиблене вивчення поєднаного застосування поліпропіленової сітки з PRF мембраною, що складається із збагаченого тромбоцитами фібрину, при хірургічному лікуванні післяопераційних вентральних гриж, зокрема у пацієнтів, які складають групи ризику. Біосумісні мембрани PRF, багаті на фактори росту, уже застосовуються в хірургічній стоматології, пародонтології, імплантології, кістковій пластиці та в щелепно-лицевій хірургії $[9,16]$. Повідомлень про використання їх у хірургічному лікуванні гриж ми не зустрічали. При застосуванні PRF мембран плазми крові стимулюється активне зростання нових капілярів, покращується кровотік, пришвидшуються обмінні процеси в тканинах, різко зростає утворення колагену, гіалуронової кислоти, значно зменшується запальний процес у ткани- 
Огляди літератури, оригінальні дослідження, погляд на проблему, ювілеї

нах [13]. Отримання інформації про динаміку цих змін допоможе розв'язати деякі тактичні завдання хворих на післяопераційну вентральну грижу.

Мета дослідження - експериментальне вивчення та морфометричне оцінювання змін артерій м'язово-апоневротичного шару тканин передньої черевної стінки після імплантації "важких", «легких" поліпропіленових сіток, а також «легких" у комбінації з PRF мембраною.

Матеріал і методи дослідження. Експериментальна робота виконана на кафедрі оперативної хірургії з топографічною анатомією Тернопільського державного медичного університету імені І. Я. Горбачевського. В експерименті використано 18 статевозрілих свиней-самців в'єтнамської породи, які були поділені на 6 груп. До 1-ї групи увійшли 3 практично здорових інтактних тварини, які перебували в звичайних умовах віварію; до 2-ї групи 3 свині з «легкою» сіткою, яку забирали разом 3 навколишніми тканинами на 14-й день експерименту, до 3-ї- 3 дослідних тварини з «легкою» сіткою, яку забирали з навколишніми тканинами на 28 добу експерименту, до 4-ї - свині з м'якою сіткою + PRE, яку забрали на 28 день експерименту; до 5-ї- 3 з свині з «важкою» сіткою, яку забирали 3 навколишніми тканинами на 14 добу експерименту, до 6-ї- 3 дослідних тварини з «важкою» сіткою, яку збирали з навколишніми тканинами на 28 добу експерименту. Дослідження проведено з дотриманням «Загальних етичних принципів експериментів на тваринах» (Україна, 2011), узгоджених 3 положенням «Європейської конвенції про захист хребетних тварин, які використовуються для екс- периментів та інших наукових цілей» (Страсбург, 1985) [5]. Виведення тварин з експерименту не проводили, згодом їх використовували в навчальних цілях на кафедрі оперативної хірургії з топографічною анатомією.

Після забору в експериментальних тварин фрагмента м'язово-апоневротичного шару передньої черевної стінки в ділянці імплантованої сітки, шматочки фіксували в 10 \% нейтральному розчині формаліну, проводили через етилові спирти зростаючої концентрації і поміщали в парафін. Отримані на санному мікротомі МС-2 зрізи товщиною 5-7 мкм після депарафінізації забарвлювали гематоксиліном і еозином за ван-Гізон, Мелорі. Світло-оптично гістологічні мікропрепарати досліджували у мікроскопах МБД-6, МБД-15, «Люман Р-8». Морфометрію здійснювали на гістологічних препаратах за допомогою окуляр-мікрометра MOB-1,5. При цьому керувалися основними засадами, викладеними в керівництві Г. Г. Автандилова (2002) [1]. На кожному мікропрепараті здійснювали 50 вимірів.

Результати й обговорення. У результаті проведених вимірювань (табл. 1) встановлено, що зовнішній діаметр артерій дрібного калібру дорівнював $(35,80 \pm 0,24)$ мкм, а внутрішній $(12,60 \pm 0,15)$ мкм, товщина медії- $(10,50 \pm 0,09)$ мкм, індекс Керногана (відношення площі просвіту до всієї площі судини) дорівнював $(12,40 \pm 0,12) \%$. Висота ендотеліоцитів цих судин досягала $(6,20 \pm$ $0,03)$ мкм, діаметр їх ядер - $(2,98 \pm 0,02)$ мкм. Ядерно-цитоплазматичні відношення у досліджуваних клітинах дорівнювали $(0,230 \pm 0,003)$.

Таблиця 1. Морфометрична характеристика артерій дрібного калібру передньої черевної стінки

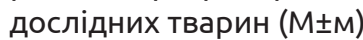

\begin{tabular}{|l|c|}
\hline \multicolumn{1}{|c|}{ Показник } & Отримана величина \\
\hline Зовнішній діаметр, мкм & $35,80 \pm 0,24$ \\
\hline Внутрішній діаметр, мкм & $12,60 \pm 0,15$ \\
\hline Товщина медії & $10,50 \pm 0,09$ \\
\hline Індекс Керногана, \% & $12,40 \pm 0,12$ \\
\hline Висота ендотеліоцитів, мкм & $6,20 \pm 0,03$ \\
\hline Діаметр ядер ендотеліоцитів, мкм & $2,98 \pm 0,02$ \\
\hline Ядерно-цитоплазматичні відношення у ендотеліоцитих & $0,230 \pm 0,003$ \\
\hline Відносний об'єм пошкоджених ендотеліоцитів, \% & $2,40 \pm 0,03$ \\
\hline
\end{tabular}

Відносний об'єм пошкоджених ендотеліоцитів дорівнював $(2,40 \pm 0,03) \%$. Варто зазначити, що це були переважно апоптично змінені клітини. У результаті морфометричних вимірювань встановлено, що у групі тварин 2М (табл. 2) відбулася виражена структурна перебудова артерій дрібного калібру передньої черевної стінки. Так, зовнішній діаметр вказаних судин збільшився всього на $0,84 \%$.
Внутрішній діаметр артерій дрібного калібру передньої черевної стінки зменшився 3 $(12,60 \pm 0,15)$ до $(11,40 \pm 0,12)$ мкм. Наведені морфометричні параметри статистично достовірно ( $<<0,01)$ відрізнялися між собою. При цьому останній кількісний морфологічний показник виявився меншим за попередній на 9,5 \%. Товщина медії у даних умовах експерименту статистично достовірно ( $p<0,01)$ збільшилася на $6,7 \%$. Індекс 
Огляди літератури, оригінальні дослідження, погляд на проблему, ювілеї

Керногана у досліджуваних експериментальних умовах з високим ступенем статистичної достовірності $(p<0,001)$ зменшився на 19,5 \%. Виявлені зміни вказаного морфометричного показника свідчили про зниження пропускної спроможності цих судин.

Таблиця 2. Морфометрична характеристика артерій дрібного калібру передньої черевної стінки 2М групи

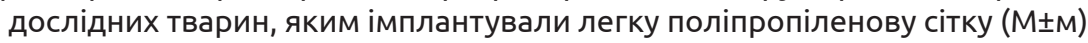

\begin{tabular}{|l|c|c|}
\hline \multicolumn{1}{|c|}{ Показник } & \multicolumn{2}{c|}{ Група спостереження } \\
\cline { 2 - 3 } & 1 -а & 2-а («легка сітка») \\
\hline Зовнішній діаметр, мкм & $35,80 \pm 0,24$ & $36,10 \pm 0,33$ \\
\hline Внутрішній діаметр, мкм & $12,60 \pm 0,15$ & $11,40 \pm 0,12^{* *}$ \\
\hline Товщина медії & $10,50 \pm 0,09$ & $9,98 \pm 0,09 * * *$ \\
\hline Індекс Керногана, \% & $12,40 \pm 0,12$ & $6,50 \pm 0,04^{* *}$ \\
\hline Висота ендотеліоцитів, мкм & $6,20 \pm 0,03$ & $3,20 \pm 0,03^{* * *}$ \\
\hline Діаметр ядер ендотеліоцитів, мкм & $2,98 \pm 0,02$ & $0,245 \pm 0,003^{*}$ \\
\hline Ядерно-цитоплазматичні відношення у ендотеліоцитих & $0,230 \pm 0,003$ & $15,60 \pm 0,15^{* * *}$ \\
\hline Відносний об'єм пошкоджених ендотеліоцитів, \% & $2,40 \pm 0,03$ & \\
\hline
\end{tabular}

Примітка. * - p<0,05; ** - p<0,01; *** - p<0,001, порівняно з 1-ю групою спостережень.

Висота ендотеліоцитів артерій дрібного калібру досліджуваних судин збільшилася 3 $(6,20 \pm 0,03)$ до $(6,50 \pm 0,04)$ мкм. Наведені морфометричні параметри статистично достовірно $(p<0,01)$ відрізнялися між собою і останній показник перевищував попередній на 4,8\%. Виявлене збільшення ендотеліоцитів можна пояснити їх набряком, який виникав у даних експериментальних умовах. Діаметр ядер ендотеліоцитів при цьому статистично достовірно $(p<0,001)$ зріс 3 $(2,98 \pm 0,02)$ до $(3,20 \pm 0,03)$ мкм, тобто на $7,4 \%$. Heрівномірне збільшення цитоплазми ендотеліоцитів та їх ядер призводило до порушення ядерно- цитоплазматичних відношень у цих клітинах (табл. 3). Вказаний морфометричний параметр статистично достовірно $(p<0,05)$ зріс на 6,5\%. Відносний об'єм пошкоджених ендотеліоцитів у даних експериментальних умовах суттєво зростав у 6,5 раза $(p<0,001)$.

Через 28 днів описані структурні зміни у артеріях дрібного калібру передньої стінки живота були суттєво меншими (табл. 3), порівняно з 2-ю групою спостережень. Так, зовнішній діаметр вказаних судин у досліджуваній групі спостережень майже не збільшився, так само не змінювався й внутрішній діаметр вказаних судин.

Таблиця 3. Морфометрична характеристика артерій дрібного калібру передньої черевної стінки

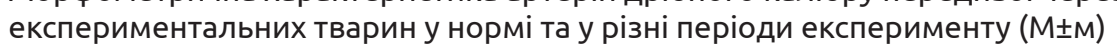

\begin{tabular}{|c|c|c|c|}
\hline \multirow[b]{2}{*}{ Показник } & \multicolumn{3}{|c|}{ Група спостереження } \\
\hline & $1-a$ & $\begin{array}{c}\text { 2-а («легка» сітка } \\
\text { 14-та доба) }\end{array}$ & $\begin{array}{c}\text { 3-я («легка» сітка } \\
\text { 28-ма доба) }\end{array}$ \\
\hline Зовнішній діаметр, мкм & $35,80 \pm 0,24$ & $36,10 \pm 0,33$ & $35,90 \pm 0,27$ \\
\hline Внутрішній діаметр, мкм & $12,60 \pm 0,15$ & $11,40 \pm 0,12 * *$ & $12,80 \pm 0,18$ \\
\hline Товщина медії & $10,50 \pm 0,09$ & $11,20 \pm 0,09 * * *$ & $10,90 \pm 0,12^{*}$ \\
\hline Індекс Керногана, \% & $12,40 \pm 0,12$ & $9,98 \pm 0,09 * *$ & $12,70 \pm 0,15$ \\
\hline Висота ендотеліоцитів, мкм & $6,20 \pm 0,03$ & $6,50 \pm 0,04 * *$ & $6,30 \pm 0,05$ \\
\hline Діаметр ядер ендотеліоцитів, мкм & $2,98 \pm 0,02$ & $3,20 \pm 0,03 * *$ & $3,08 \pm 0,04 *$ \\
\hline $\begin{array}{l}\text { Ядерно-цитоплазматичні } \\
\text { відношення у ендотеліоцитих }\end{array}$ & $0,230 \pm 0,003$ & $0,245 \pm 0,003 *$ & $0,240 \pm 0,005$ \\
\hline $\begin{array}{l}\text { Відносний об'єм пошкоджених } \\
\text { ендотеліоцитів, \% }\end{array}$ & $2,40 \pm 0,03$ & $15,60 \pm 0,15$ & $4,10 \pm 0,05^{* * *}$ \\
\hline
\end{tabular}

Примітка. * - p<0,05; ** - p <0,01; *** - p <0,001, порівняно з 1-ю групою спостережень.

Товщина медії вказаних судин через 28 днів після експерименту дорівнювала $(10,90 \pm 0,12)$ мкм. Даний морфометричний параметр на 3,8 \% перевищував аналогічний контрольний і статистично достовірно $(p<0,05)$ контрольний $(p<0,05)$ від нього відрізнявся. Індекс Керногана при цьому суттєво не відрізнявся від аналогічного контрольного показника. 
Огляди літератури, оригінальні дослідження, погляд на проблему, ювілеї

Висота ендотеліоцитів, діаметр їх ядер та ядерно-цитоплазматичне відношення у ендотеліоцитах суттєво не відрізнялися від аналогічних контрольних параметрів. Відносний об'єм пошкоджених ендотеліоцитів артерій дрібного калібру

передньої черевної стінки через 28 діб від початку експерименту дорівнював $(4,10 \pm 0,05) \%$. Даний морфометричний показник з високим ступенем статистичної достовірності ( $<<0,001)$ перевищував аналогічний контрольний у 1,7 раза (табл. 4).

Таблиця 4. Морфометрична характеристика артерій дрібного калібру передньої черевної стінки

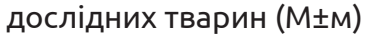

\begin{tabular}{|l|c|c|}
\hline \multicolumn{1}{|c|}{ Показник } & \multicolumn{2}{c|}{ Група спостереження } \\
\cline { 2 - 3 } & $\begin{array}{c}1 \text {-а } \\
\text { контроль }\end{array}$ & $\begin{array}{c}\text { 4-а } \\
\text { «легка» сітка+ PRF (28 доба експерименту) }\end{array}$ \\
\hline Зовнішній діаметр, мкм & $35,80 \pm 0,24$ & $35,82 \pm 0,27$ \\
\hline Внутрішній діаметр, мкм & $12,60 \pm 0,15$ & $12,65 \pm 0,18$ \\
\hline Індекс Керногана,\% & $12,40 \pm 0,12$ & $12,46 \pm 0,15$ \\
\hline Висота ендотеліоцитів, мкм & $6,20 \pm 0,03$ & $6,24 \pm 0,05$ \\
\hline Діаметр ядер ендотеліоцитів, мкм & $2,98 \pm 0,02$ & $3,02 \pm 0,04$ \\
\hline Ядерно-цитоплазматичні відношення & $0,230 \pm 0,003$ & $0,234 \pm 0,005$ \\
\hline Відносний об'єм пошкоджених ендотеліоцитів, \% & $2,40 \pm 0,03$ & $2,60 \pm 0,09 *$ \\
\hline
\end{tabular}

Примітка. * - p<0,05, порівняно з 1-ю групою.

У результаті всестороннього аналізу отриманих даних встановлено, що більшість морфометричних параметрів артерій дрібного калібру передньої черевної стінки не відрізнялися від аналогічних показників 1-ї групи спостережень (інтактні тварини контрольної групи).

Дещо зміненим при цьому виявився відносний об'єм пошкоджених ендотеліоцитів у артеріях дрібного калібру передньої черевної стінки. Так, у 1-й групі спостережень вказаний морфометричний параметр становив $(2,40 \pm 0,03) \%$, а у 4-й - $(2,60 \pm 0,09) \%$. Наведені морфометричні параметри статистично достовірно $(p<0,05)$ відрізнялися між собою і останній морфометричний параметр перевищував попередній на 8,3 \%. Збільшення кількості пошкоджених ендотеліоцитів можна пов'язати із зростанням числа апоптично змінених клітин, що пов'язано з операційним стресом.

Результати морфометрії артерій дрібного калібру передньої черевної стінки 5-ї (3м) групи показані у таблиці 5 («важка» сітка, 14 діб).

Таблиця 5. Морфометрична характеристика артерій дрібного калібру передньої черевної стінки

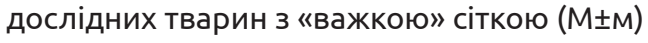

\begin{tabular}{|l|c|c|}
\hline \multicolumn{1}{|c|}{ Показник } & \multicolumn{2}{c|}{ Група тварин } \\
\cline { 2 - 3 } & 1 -а & 5-а («важка» сітка 14-та доба) \\
\hline Зовнішній діаметр, мкм & $35,80 \pm 0,24$ & $36,15 \pm 0,30$ \\
\hline Внутрішній діаметр, мкм & $12,60 \pm 0,15$ & $11,46 \pm 0,12^{* *}$ \\
\hline Товщина медії & $10,50 \pm 0,04$ & $11,30 \pm 0,09^{* *}$ \\
\hline Індекс Керногана, \% & $12,40 \pm 0,12$ & $10,05 \pm 0,12^{* * *}$ \\
\hline Висота ендотеліоцитів, мкм & $6,20 \pm 0,03$ & $6,55 \pm 0,04^{* * *}$ \\
\hline Діаметр ядер ендотеліоцитів, мкм & $2,98 \pm 0,02$ & $3,25 \pm 0,04^{* *}$ \\
\hline Ядерно-цитоплазматичні відношення & $0,230 \pm 0,003$ & $0,246 \pm 0,003^{* *}$ \\
\hline Відносний об'єм пошкоджених ендотеліоцитів, \% & $2,40 \pm 0,03$ & $15,80 \pm 0,18^{* * *}$ \\
\hline
\end{tabular}

Примітка. ** - p<0,01; *** - p<0,001, порівняно з 1-ю групою спостережень.

У результаті всестороннього аналізу отриманих морфометричних показників встановлено, що зовнішній діаметр вказаних артерій у даних умовах експерименту зріс на 0,97 \%. Просвіт вказаних судин зменшився при цьому на 9,0 \% ( $<<0,01)$. Товщина медії досліджуваних артерій у даних експериментальних умовах статистично достовірно ( $<<0,01)$ збільшилася, $3(10,50 \pm 0,09)$ до $(11,30 \pm 0,09)$ мкм, тобто на $7,6 \%$.
Індекс Керногана з високим ступенем статистичної достовірності ( $<<0,001)$ зменшився на $18,9 \%$ що свфідчить про зниження пропускної спроможності досліджувальних судин.

Висота ендотеліоцитів артерій дрібного калібру збільшилася на 5,6 \%, діаметр їх ядер - на $9,1 \%$ ( $<<0,01)$. Ядерно-цитоплазматичні відношення у досліджувальних клітинах зросли 3 $(0,230 \pm 0,003)$ до $(0,246 \pm 0,003)$. Наведені морфо- 
Огляди літератури, оригінальні дослідження, погляд на проблему, ювілеї

метричні параметри статистично достовірно ( $<<0,01)$ відрізнялися між собою, при цьому останній морфометричний параметр перевищував попередній на 6,9 \%.

Відносний об'єм пошкоджених ендотеліоцитів у досліджуваних умовах експерименту статистично достовірно ( $<<0,001)$ збільшився у 6,6 раза.

Морфометричні параметри артерій дрібного калібру 6-ї групи спостережень представлені у таблиці 6. Встановлено, що зовнішній діаметр вказа- них судин збільшився всього на 0,22 \%, а внутрішній діаметр майже не змінився і дорівнював $(12,70 \pm 0,18)$ мкм. Товщина медії артерій дрібного калібру передньої черевної стінки виявилася збільшеною і досягала $(10,92 \pm 0,15)$ мкм. Наведений морфометричний параметр статистично достовірно $(p<0,05)$ відрізнявся від аналогічного контрольного - $(10,50 \pm 0,09)$ мкм. Виявлена різниця між наведеними морфометричними параметрами дорівнювала 4,0 \%.

Таблиця 6. Морфометрична характеристика артерій дрібного калібру передньої черевної стінки

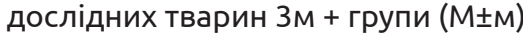

\begin{tabular}{|l|c|c|}
\hline \multicolumn{1}{|c|}{ Показник } & \multicolumn{2}{c|}{ Група спостережень } \\
\cline { 2 - 3 } & 1 -а & $\begin{array}{c}\text { 6-а } \\
\text { «важка» сітка (28 діб) }\end{array}$ \\
\hline Зовнішній діаметр, мкм & $35,80 \pm 0,24$ & $35,88 \pm 0,27$ \\
\hline Внутрішній діаметр, мкм & $12,60 \pm 0,15$ & $12,70 \pm 0,18$ \\
\hline Товщина медії & $10,50 \pm 0,09$ & $10,92 \pm 0,15^{*}$ \\
\hline Індекс Керногана, \% & $12,40 \pm 0,12$ & $12,82 \pm 0,15^{*}$ \\
\hline Висота ендотеліоцитів, мкм & $6,20 \pm 0,03$ & $3,26 \pm 0,04$ \\
\hline Діаметр ядер ендотеліоцитів, мкм & $2,98 \pm 0,02$ & $0,242 \pm 0,03$ \\
\hline Ядерно-цитоплазматичні відношення & $0,230 \pm 0,003$ & $4,90 \pm 0,05^{* * *}$ \\
\hline Відносний об'єм пошкоджених ендотеліоцитів, \% & $2,40 \pm 0,03$ & \\
\hline
\end{tabular}

Примітка: * - p<0,05; *** - p<0,001, порівняно з 1-ю групою спостережень.

Структура ендотеліоцитів у даних експериментальних умовах не змінювалася, що підтверджувалося такими морфометричними параметрами як висота ендотеліоцитів, діаметр їх ядер, ядерно-цитоплазматичне відношення у цих клітинах.

3 високим ступенем достовірності $(p<0,001)$ у даних умовах експерименту виявився зміненим відносний об'єм пошкоджених ендотеліоцитів у артеріях дрібного калібру передньої черевної стінки. Так, у контрольній групі спостережень даний морфометричний параметр дорівнював $(2,40 \pm$ 0,03) \%, а у 5-й групі спостережень - $(4,90 \pm 0,5) \%$. Наведені морфометричні показники статистично достовірно (p<0,001) між собою відрізнялися і

\section{ЛІТЕРАТУРА}

1. Автандилов Г. Г. Морфометрия в патологии / Г. Г. Автандилов.- М. : Медицина, 2002. - 240 с.

2. Бондарев Р. В. Структурная основа клинического прогнозирования репаративных процессов в послеоперационном периоде у пациентов с послеоперационными грыжами передней брюшной стенки / 3. В. Бондарев, А. Л. Чибисов // Хірургія України. - 2008. - № 2, додаток. - С. 83-85.

3. Дзюбановський І. Я. Ранові ускладнення після алогерніопластики післяопераційної грижі черевної стінки / І. Я. Дзюбановський, В.І.П'ятночка // Клінічна хірургія. - 2009. - № 11 / 12. - С. 33-34. останній морфометричний параметр перевищував попередній у 2 рази.

Висновок. У результаті морфометричних вимірювань артерій дрібного калібру встановлено що імплантація «легкої» сітки, порівняно із «важкою», у віддаленому періоді експерименту призводила до вираженішого ремоделювання досліджуваних судин, що підтверджувалося відносними об'ємами пошкоджених ендотеліоцитів, які, відповідно, дорівнювали $(4,10 \pm 0,05) \%$ та $(4,90 \pm 0,05) \%$. Використання для імплантації легкої сітки з PRF мембраною приводило до найменш вираженої структурної перебудови артерій, тому даний метод слід вважати пріоритетним при хірургічному лікуванні хворих на первинну та інцизійну вентральну грижу.

4. Профілактика ранових гнійних ускладнень післяопераційних гриж черевної стінки / В. І. Лупальцов, А. І. Ягнюк, І. А. Дехтярук, Р. С. Ворощук // Клінічна хірургія. - 2010. - № 1. - С. 58.

5. Лабораторні тварини в медико-біологічних експериментах : метод. посіб. / В. П. Пішак, В. Г. Висоцька, В. М. Магаляс [та ін.]. - Ч. : Медуніверситет, 2006. - 350 с.

6. Експлантація сіток при ускладеннях алогерніопластики, показання та профілактика / Я. П. Фелештинський, В. Ф. Ватаманюк, С. А. Свиридовський, В. О. Дубенець // Львівський медичний часопис. - 2009. - Т. 15, № 2. - С. 61-64. 
Огляди літератури, оригінальні дослідження, погляд на проблему, ювілеї

7. Четверіков С. Г. Проблемні питання аллопластики вентральних гриж / С. Г. Четверіков, В. Ю. Вододюк, М. В. Чехлов // Хірургія України. - 2008. - № 2 (26). (Додаток). - С. 81-83.

8. Beets G. L. Foreign body reactions to monofilament and braided polypropylene mesh used as preperitoneal implants in pigs / G. L. Beets, P. M. Go, H. van Mameren // Eur. J. Surg. - 1996. - Vol. 162 (10). - P. 823-825.

9. Combination of platelet rich fibrin, hydroxyapatite and PRF membrane in the management of large inflammatory periapical lesion / V. Y. Shivashankar, D. A. Johns, S. Vidyanath, S. Sam // J. Conserv. Dent. - 2013. - Vol. 16, No. 3. - P. 261-264.

10. Chung L. Outcome of patients with chronic mesh infection following abdominal wall hernia repair / L. Chung, G. H. Tse, P. J. O’Dwyer // Hernia. -2014. - Vol. 18, No. 5. P. 701-704.

11. Matyja A. Local reaction to polypropylene mesh histopatological findings / A. Matyja, R. Solecki, J. Heitzman // Hernia Recurrences. - Praga, 2004. - P. 63.

\section{REFERENCES}

1. Avtandilov, G.G. (2002). Morfometriya v patologii [Morphometry in pathology]. Moscow: Meditsina [in Russian].

2. Bondarev, R.V., \& Chibisov, A.L. (2008). Strukturnaya osnova klinicheskogo prognozirovaniya reperativnykh protsessov v posleoperatsionnom periode u patsiyentov s posleoperatsionnymi gryzhami peredney bryushnoy stenki [Structural basis of the clinical prediction of the regenerative processes in the postoperative period in patients with postoperative hernias of the anterior abdominal wall]. Khirurhiia Ukrainy - Surgery of Ukraine, 2 (26), 83-85 [in Russian].

3. Dziubanovskyi, I.Ya., \& Piatnochka, V.I. (2009). Ranovi uskladnennia pislia alohernioplastyky pisliaoperatsiinoi hryzhi cherevnoi stinky [Early complications after alohernioplasty of the postoperative hernia of the abdominal wall]. Klinichna khirurhiia-Clinical Surgery, 11/12, 33-34 [in Ukrainian].

4. Lupaltsov, V.I., Yahniuk, A.I., Dekhtiaruk, I.A., \& Voroshchuk, R.S. (2010). Profilaktyka ranovykh hniinykh uskladnen pisliaoperatsiinykh hryzh cherevnoi stinky [Prevention of wound purulent complications of postoperative hernia of the abdominal wall]. Klinichna khirurhiia - Clinical Surgery, 1, 58 [in Ukrainian].

5. Pishak, V.P., Vysotska, V.H., \& Mahalias, V.M. (2006). Laboratorni tvaryny $v$ medyko-biolohichnykh eksperymentakh: metod. posib. [Laboratory animals in medical and biological experiments: method. manual]. Chernivtsi: Meduniversytet [in Ukrainian].

6. Feleshtynskyi, Ya.P., Vatamaniuk, V.F., Svyrydovskyi, S.A., \& Dubenets, V.O. (2009). Eksplantatsiia sitok pry uskladenniakh alohernioplastyky, pokazannia ta profilaktyka [Exteriorization of meshes with complications of alohernioplasty, indications and prophylaxis]. Lvivskyi medychnyi chasopys - Lviv Medical Journal, 15, 2, 61-64 [in Ukrainian].
12. Offner F. A. Meshes: benefits and risks / F. A. Offner, V. Schumpelich ed. -Berlin, 2004. - P. 161-169.

13. Platelet-rich fibrin (PRF): A second-generation platelet concentrate. Part IV: Clinical effects on tissue healing / J. Choukroun, A. Diss, A. Simonpieri [et al.] // Oral Surg. Oral Med. Oral Pathol. Oral Radiol. Endod. -2006. - Vol. 101, No. 3. - P. 56-60.

14. Rosen M. J. Evaluation of surgical outcomes of retro-rectus versus intraperitoneal reinforcement with bio-prosthetic mesh in the repair of contaminated ventral hernias / M. J. Rosen // Hernia. - 2012. - Vol. 16, No. 1. P. $152-156$.

15. Schumpelick V. Meshes: benefits and risks / V. Schumpelick, L. Nygus. Springer-Verlag: Berlin, 2003. $112 \mathrm{p}$.

16. Thorat M. Clinical effect of autologous plateletrich fibrin in the treatment of intra-bony defects: A controlled clinical trial / M. Thorat, A. R. Pradeep, B. Pallavi // J. Clin. Periodontol. - 2011. - Vol. 38 (10). - P. 925-932. doi: 10.1111/j.1600-051X.2011.01760.x.

7. Chetverikov, S.H., Vododiuk, V.Yu., \& Chekhlov, M.V. (2008). Problemni pytannia alloplastyky ventralnykh hryzh [Problematic questions of alloplasty of ventral hernias]. Khirurhiia Ukrainy - Surgery of Ukraine, 2 (26), (Dodatok), 81-83 [in Ukrainian].

8. Beets, G.L., Go, P.M., \& Mameren, H. van (1996). Foreign body reactions to monofilament and braided polypropylene mesh used as preperitoneal implants in pigs. Eur. J. Surg., 162 (10), 823-825.

9. Shivashankar, V.Y., Johns, D.A., \& Vidyanath, S., \& Sam, S. (2013). Combination of platelet rich fibrin, hydroxyapatite and PRF membrane in the management of large inflammatory periapical lesion. J. Conserv. Dent., 16 (3), 261-264.

10. Chung, L.G., Tse, H., \& O'Dwyer, P.J. (2014). Outcome of patients with chronic mesh infection following abdominal wall hernia repair. Hernia, 18 (5), 701-704.

11. Matyja, A., Solecki, R., \& Heitzman, J. (2004). Local reaction to polypropylene mesh - histopatological findings. Hernia Recurrences. Praga.

12. Offner, F.A., \& Schumpelich, V. (Eds.). (2004). Meshes: benefits and risks. Berlin.

13. Choukroun, J., Diss, A., \& Simonpieri, A. (2006). Platelet-rich fibrin (PRF): A second-generation platelet concentrate. Part IV: Clinical effects on tissue healing. Oral Surg. Oral Med. Oral Pathol. Oral Radiol. Endod., 101 (3), 56-60.

14. Rosen, M.J. (2012). Evaluation of surgical outcomes of retro-rectus versus intraperitoneal reinforcement with bio-prosthetic mesh in the repair of contaminated ventral hernias. Hernia, 16 (1), 152-156.

15. Schumpelick, V., \& Nygus, L. (2003). Meshes: benefits and risks. Springer-Verlag: Berlin.

16. Thorat, M., Pradeep, A.R., \& Pallavi, B. (2011). Clinical effect of autologous platelet-rich fibrin in the treatment of intra-bony defects: A controlled clinical trial. J. Clin. Periodontol., 38 (10), 925-932. doi: 10.1111/j.1600-051X. 2011.01760.x. 


\title{
Огляди літератури, оригінальні дослідження, погляд на проблему, ювілеї \\ СРАВНИТЕЛЬНАЯ МОРФОМЕТРИЧЕСКАЯ ОЦЕНКА ПРОЦЕССОВ РЕГЕНЕРАЦИИ ТКАНЕЙ ПЕРЕДНЕЙ БРЮШНОЙ СТЕНКИ ПОСЛЕ ИМПЛАНТАЦИИ РАЗЛИЧНЫХ ТИПОВ ПОЛИПРОПИЛЕНОВЫХ СЕТОК В ЭКСПЕРИМЕНТЕ
}

\author{
๑В. И. Пятночка, М. С. Гнатюк
}

ГВУз «Тернопольский государственный медицинский университет имени И. Я. Горбачевского МОЗ Украины»

РЕзюМЕ. Широкое внедрение в хирургическую практику современных аллопластических материалов существенно улучшило результаты хирургического лечения больных с вентральной и послеоперационной вентральной грыжами. Однако имплантация синтетического материала в ткани передней брюшной стенки сопровождается разными местными реакциями, особенно при использовании "тяжелых» сеток, что часто приводит к развитию осложнений. Необходимость анализа полученных результатов обуславливает актуальность данного исследования.

Цель работы - провести морфометрическую оценку изменений артерий мышечно-апоневротического слоя после имплантации «тяжелых» и «легких» полипропиленовых сеток и «легких» в сочетании с PRF мембраной.

Материал и методы. Морфометрический анализ артерий мышечно-апоневротического слоя после имплантации «тяжелых», «легких» полипропиленовых сеток, а также «легких» в сочетании с PRF мембраной, при помощи светооптического исследования микропрепаратов. Эксперименты выполнены на 18 половозрелых свиньяхсамцах вьетнамской породы, которые были поделены на 6 групп.

Результаты. Измерения, проведенные в группе интактных животных, показали, что внешний диаметр артерий мелкого калибра равен $(35,80 \pm 0,24)$ мкм, внутренний - $(12,60 \pm 0,15)$ мкм, толщина медии - $(10,50 \pm 0,09)$ мкм, индекс Керногана (отношение площади просвета ко всей площади сосуда) составил $(12,40 \pm 0,12) \%$. Высота эндотелиоцитов этих сосудов достигала $(6,20 \pm 0,03)$ мкм, диаметр их ядер - $(2,98 \pm 0,02)$ мкм. Ядерно-цитоплазматические соотношения в исследуемых клетках составили $(0,230 \pm 0,003)$. На 28-е сутки эксперимента в условиях имплантации «легкой» сетки толщина медии сосудов равнялась $(10,90 \pm 0,12)$ мкм. Данный морфометрических параметр на 3,8 \% превышал аналогичный контрольный и статистически достоверно $(p<0,05)$ от него отличался. При имплантации «легкой» сетки в сочетании с PRF мембраной отмечено изменения относительного объема поврежденных эндотелиоцитов в артериях мелкого калибра. В 1-й группе наблюдений указанный морфометрический параметр равен $(2,40 \pm 0,03)$ \%, а в 4-й $(2,60 \pm 0,09) \%$. Морфометрические параметры артерий мелкого калибра при имплантации «тяжелой» сетки были следующими: внешний диаметр указанных сосудов увеличился всего на $0,22 \%$, а внутренний диаметр почти не изменился и был равен $(12,70 \pm 0,18)$ мкм. Толщина медии артерий мелкого калибра передней брюшной стенки оказалась увеличенной и достигала $(10,92 \pm 0,15)$ мкм. Указаный морфометрический параметр статистически достоверно $(p<0,05)$ отличался от аналогичного контрольного $(10,50 \pm 0,09)$ мкм. Установленная разница между приведенными морфометрическими параметрами равнялась 4,0%.

Выводы. В результате морфометрических измерений артерий мелкого калибра установлено, что имплантация «легкой» сетки, по сравнению с «тяжелой», в отдаленном периоде эксперимента приводила к выраженному ремоделированию исследуемых сосудов, что подтверждалось относительным объемом поврежденных эндотелиоцитов $(4,10 \pm 0,05)$ \% и $(4,90 \pm 0,05)$ \%. Использование для имплантации легкой сетки с PRF мембраной приводило к наименее выраженным структурным изменениям артерий.

КЛЮЧЕВЫЕ СЛОВА: имплантация; полипропиленовая сетка; морфометрия артерій; толщина медии; индекс Керногана.

\section{COMPARATIVE MORPHOMETRIC ASSESSMENT OF REGENERATION PROCESSES OF THE ANTERIOR ABDOMINAL WALL TISSUES AFTER IMPLANTATION OF VARIOUS TYPES OF POLYPROPYLENE MESHES IN THE EXPERIMENT}

\section{@V. I. Piatnochka, M. S. Gnatiuk \\ I. Horbachevsky Ternopil State Medical University}

SUMMARY. The widespread introduction of modern alloplastic materials into the surgical practice has significantly improved the results of surgical treatment of patients with ventral and postoperative ventral hernia. However, the implantation of synthetic material in the tissue of the anterior abdominal wall is accompanied by different local reactions, especially when using "heavy" meshes, which often leads to the development of complications. Analysis of the results determines the relevance of this study.

The aim of the study - to conduct a morphometric assessment of changes in the arteries of the muscular aponeurotic layer after implantation of "heavy" and "light" polypropylene meshes and "light" in combination with a PRF membrane.

Materials and Methods. Morphometric analysis of the arteries of the musculo-aponeurotic layer after the implantation of "heavy", "light" polypropylene meshes and "light" in combination with the PRF membrane in a lightoptical study of microscopic preparations. The experiments were performed on 18 mature male pigs of the Vietnamese breed, which were divided into 6 groups. 
Огляди літератури, оригінальні дослідження, погляд на проблему, ювілеї

Results and its Discussion. The measurements in the group of intact animals showed that the outer diameter of the arteries of small caliber is $(35.80 \pm 0.24) \mu \mathrm{m}$, the internal diameter is $(12.60 \pm 0.15) \mu \mathrm{m}$, the thickness of the media is $(10.50 \pm 0.09) \mu \mathrm{m}$, the Kernogan index (the ratio of the lumen area to the entire area of the vessel) is equal to $(12.40 \pm 0.12) \%$. The height of the endotheliocytes of these vessels reached $(6.20 \pm 0.03) \mu \mathrm{m}$, the diameter of their nuclei $-(2.98 \pm 0.02) \mu \mathrm{m}$. Nuclear-cytoplasmic relations in the studied cells were - $(0.230 \pm 0.003)$. On the 28 th day of the experiment under conditions of implantation of a light mesh, the thickness of the media vessels is equal to $(10.90 \pm 0.12) \mu \mathrm{m}$. This morphometric parameter was $3.8 \%$ higher than the same control and statistically significantly $(p<0.05)$ control and was statistically significantly $(p<0.05)$ different from it. During the implantation of the "light" mesh in combination with the PRF membrane, changes in the relative volume of damaged endothelial cells in the arteries of small caliber were noted. In the group 1 of observations, the indicated morphometric parameter is $(2.40 \pm 0.03) \%$, and in the group $4(2.60 \pm 0.09) \%$. Morphometric parameters of small-caliber arteries during the implantation of a "heavy" mesh showed an increase in the backward diameter of these vessels by only $0.22 \%$, and the internal diameter was almost unchanged and equal to $(12.70 \pm 0.18) \mu \mathrm{m}$. The thickness of the media arteries of small caliber of the anterior abdominal wall was increased and reached $(10.92 \pm 0.15) \mu \mathrm{m}$. The given morphometric parameter was statistically significantly $(p<0.05)$ different from the similar control (10.50 \pm 0.09$) \mu \mathrm{m}$. The revealed difference between the given morphometric parameters was equal to $4.0 \%$.

Conclusions. Morphometric measurements of small-caliber arteries established implantation of a "light" mesh compared to a "heavy" in the vitality period of the experiment led to pronounced re-modeling of the vessels under study, which was confirmed by relative volumes of damaged endothelial cells, which is $(4.10 \pm 0.05) \%$ and $(4.90 \pm 0.05) \%$. The use of a light mesh with a PRF membrane for implantation resulted in the least pronounced structural reorganization of the arteries.

KEY WORDS: implantation; polypropylene mesh; artery morphometry; media thickness; Kernogan index.

Отримано 05.11 .18 